\title{
Deficiency of Carnitine in Cachectic Cirrhotic Patients
}

\author{
Daniel Rudman, Charles W. Sewell, and Joseph D. Ansley \\ From the Departments of Medicine, Pathology, and Surgery, Emory University School of Medicine, \\ and the Clinical Research Facility, Emory University Hospital, Atlanta, Georgia 30322
}

A B S T RACT Carnitine is synthesized from lysine and methionine. In the rat, inadequate intake of either of these essential amino acids causes carnitine depletion. Inasmuch as protein deficiency is common in the hospital population, we have investigated the possible occurrence of nosocomial carnitine deficiency. Fasting serum carnitine concentration was measured in 16 normal and 247 patients in 16 disease groups. Normal range of carnitine was $55-103 \mu \mathrm{M}$. Only the cirrhotic group showed significant $(P<0.05)$ hypocarnitinemia. 14 of 36 hospitalized cirrhotics had subnormal values for serum carnitine. The creatinine/height index, midarm muscle circumference, and triceps skin-fold thickness indicated protein-calorie starvation in the 14 hypocarnitinemic liver patients. In six of the hypocarnitinemic cirrhotics (average serum level $50 \%$ of normal), spontaneous dietary intakes of carnitine, lysine, and methionine were measured and found to be only $5-15 \%$ as great as in six normocarnitinemic, healthy controls. When these six cirrhotic and six normal subjects were given the same lysine-rich, methionine-rich, and carnitine-free nutritional intake, the normals maintained normal serum carnitine levels and excreted $100 \mu \mathrm{mol} / \mathrm{day}$, whereas the cirrhotics' serum level fell to $25 \%$ of normal, and urinary excretion declined to $15 \mu \mathrm{mol} / \mathrm{day}$.

Seven hypocarnitinemic cirrhotics died. Postmortem concentrations of carnitine in liver, muscle, heart, kidney, and brain averaged only one-fourth to onethird those in corresponding tissues of eight normally nourished nonhepatic patients who died after an acute illness of a 1-3-day duration.

These data show that carnitine depletion is common in patients hospitalized for advanced cirrhosis, and that it results from three factors: substandard intake of dietary carnitine; substandard intake of lysine and methionine, the precursors for endogenous carnitine synthesis; and loss of capacity to synthesize carnitine from lysine and methionine.

Received for publication 7 February 1977 and in revised form 18 April 1977.

\section{INTRODUCTION}

Carnitine is a trimethylated $\gamma$-amino acid which is present in all mammalian tissues. It plays an essential role in fatty acid oxidation because fatty acids must be esterified with carnitine in order to be transported from the cytoplasm into mitochondria, where the oxidation occurs (1). The body's supply of carnitine is derived in part by ingestion of preformed dietary carnitine, and in part by endogenous synthesis from the essential amino acids lysine and methionine (2-5). Step 3 in the synthetic pathway (Fig. 1) takes place primarily in the liver.

Several cases of human carnitine deficiency have been reported since $1973(6-9)$. The clinical manifestations have included low concentration of carnitine in plasma, muscle, and liver, muscle weakness and atrophy, lipid accumulation in muscle cells, and hepatic and cerebral dysfunction. Presently carnitine deficiency is considered a rare syndrome caused by an inherited defect in carnitine biosynthesis.

Nevertheless, carnitine deficiency can be readily produced in rats by a carnitine-free diet deficient in either lysine $(10,11)$ or methionine (11). The combination of zero intake of preformed carnitine and inadequate intake of the precursors for endogenous carnitine synthesis leads to progressive reduction in the

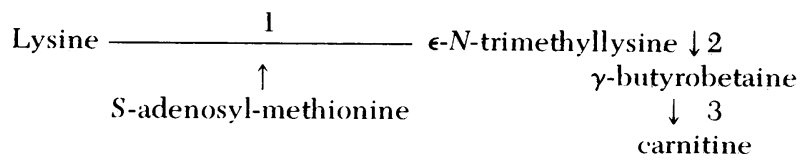

FIguRE 1 Biosynthesis of carnitine,

$$
\left(\mathrm{CH}_{3}\right) \mathrm{N}^{+} \mathrm{CH}_{2} \mathrm{CH}_{2} \mathrm{CH}_{2} \mathrm{COO}^{-} .
$$

The carbon chain is derived from $C_{4}$ to $C_{6}$ of lysine, the $N$ is derived from $\epsilon-N$ of lysine, and the methyl groups from methionine. Steps 1 and 2 occur in most tissues, step 3 primarily in liver. 
concentration of the methylated amino acid in plasma, tissues, and urine. The carnitine-deficient rats develop a fatty liver which is improved by a dietary supplement of carnitine $(10,11)$.

Protein deficiency is currently prevalent within the hospital population. Recent surveys have revealed evidence of protein-calorie undernutrition in about one-third of patients on the medical and surgical services in two hospitals $(12,13)$. The rapid development of carnitine deficiency in rats fed a diet deficient in essential amino acids suggested to us that unrecognized carnitine deficiency could be endemic in patients with nosocomial malnutrition. The present study was designed to test this idea.

\section{METHODS}

Experimental design. The study proceeded in three phases.

Phase A. Carnitine level in serum was measured in 16 normal subjects and 247 hospital patients in 16 disease categories. All sera were drawn at 7-9 a.m. while the subjects were fasting. 14 cirrhotic patients with hypocarnitinemia were identified.

Phase B. To investigate the cause of the subnormal plasma carnitine level in the 14 cirrhotics, 6 were transferred to the metabolic research unit for an 18-day study. During days 1-6, their spontaneous dietary intake of carnitine, lysine, and methionine was measured, together with the simultaneous serum and urine levels of carnitine. They then received for 6 days carnitine-free oral and parenteral nutrition providing two to three times the recommended daily allowance (RDA) ${ }^{1}$ of lysine and methionine, while serum concentration and urinary excretion of carnitine continued to be monitored. During days 13 to 18 , a carnitine supplement was added to the carnitine-free nutrition. In phase $B$, six normal individuals served as controls.

Phase C. Seven of the hypocarnitinemic cirrhotics studied under phase $\mathrm{A}$ died and were brought to autopsy. Tissue levels of carnitine in liver, kidney, muscle, and brain were measured. Controls for phase $\mathrm{C}$ were eight normally nourished, nonhepatic patients who died after an acute illness lasting 1-3 days.

Subjects. Tables I, II, and IV give clinical data for the individuals studied under phases $\mathrm{A}, \mathrm{B}$, and $\mathrm{C}$, respectively. Nutritional status of the subjects was evaluated by body weight as percentage of ideal if ascites and edema were absent (14), midarm muscle circumference (MAMC) and triceps skin-fold thickness (TSF) $(15,16)$, creatinine/height ratio (17), and serum albumin level and hematocrit.

Carnitine analysis. Free and total (i.e., free plus esterified) L-carnitine were determined enzymatically by the coupled spectrophotometric assay of Marquis and Fritz (18) in plasma (19), urine (20), tissue (21), and food (21). Preliminary experiments showed that carnitine contents of rat tissues did not change detectably while the carcass was stored for $24 \mathrm{~h}$ at $5^{\circ} \mathrm{C}$. Human tissues were obtained at autopsy within $8 \mathrm{~h}$ after death.

Diets. During phase A, diet was ad lib. and unmeasured. During the first 6 days of phase B, subjects ate ad lib. menus

${ }^{1}$ Abbreviations used in this paper: MAMC, midarm muscle circumference; RDA, recommended daily allowance; TSF, triceps skin-fold thickness. constructed from 25 foods of known carnitine (Table V), lysine (22), and methionine (22) contents, and their intake of each food was measured. During the next 6 days, the normal subjects were fed an oral diet containing $<10$ $\mu$ mol carnitine/day, 2,200-2,400 calories, and 80-90 g protein or amino acids containing 3,200-3,400 mg lysine and 2,000$2,200 \mathrm{mg}$ methionine. The cirrhotic patients, because of anorexia, received $300-800 \mathrm{ml}$ Freamine II (McGaw Labs., Glendale, Calif.) and $300-1,000 \mathrm{ml} 10 \%$ glucose intravenously each day to achieve the same intakes $( \pm 15 \%)$ of carnitine, calories, and amino acids as the healthy controls. During days 13-18 of phase $B$, the intakes were the same as during days 6-12 except that an oral supplement of 500 $\mu$ mol D,L-carnitine (Sigma Chemical Co., St. Louis, Mo.) was added. For patients studied under phase $C$, no information on dietary intake during the months before death was available.

\section{RESULTS}

Phase A. Table I shows the results of surveying serum carnitine level in 16 normals, 211 nonhepatic patients, and 36 cirrhotics. In the normal group, average $\pm S E$ for serum-total carnitine was $79 \pm 3 \mu \mathrm{M}$; thus, the normal range, defined as average $\pm 2 \mathrm{SD}$, was 55-103 $\mu \mathrm{M}$. For serum-free carnitine, normal average was $49 \mu \mathrm{M}$ and normal range was 25-73 $\mu \mathrm{M}$. In 16 nonhepatic disease groups, average values for serum-total and serum-free carnitine did not differ significantly $(P>0.05)$ from normal (Table I). In the cirrhotic group, contrastingly, average ranges for both total and free concentrations were significantly depressed $(P<0.05)$. In 14 of the 36 cirrhotics, the serum level was below the normal range (total $<55$ $\mu \mathrm{M}$, free $<25 \mu \mathrm{M}$ ).

Nutritional evaluation of the 14 hypocarnitinemic cirrhotics, as compared to the 16 normals (Table VI), showed severely reduced creatinine/height index, MAMC, and TSF, consistent with advanced proteincalorie starvation $(14,15,17)$. The hypocarnitinemic cirrhotics also had severe hepatocellular disease, as revealed by the plasma levels of albumin, bilirubin, and prothrombin (Table VI). In the 22 normocarnitinemic cirrhotics, indices of nutritional status and hepatocellular function were intermediate between those of the hypocarnitinemic liver patients and the normal controls (Table VI).

Phase B. Six of the cirrhotic patients with subnormal serum carnitine were transferred to the metabolic research unit for phase $B$. The clinical data (Table II) showed all six patients to have severe (Childs Class C [23]) liver disease of $>$ a 6 -yr duration. Body weight was not useful for evaluation of nutrition because of ascites, but MAMC, TSF, and creatinine/height ratio were uniformly $<70 \%$ of standard, albumin was $<2.5 \mathrm{~g} / 100 \mathrm{~g}$, and hematocrit was $<30 \%$. During days 1-6 of phase B, all six hypocarnitinemic cirrhotics were found to be markedly anoretic. Their spontaneous ad lib. intake of calories, carbohydrate, 
TABLE 1

Phase A of the Study: Fasting Serum Carnitine Concentration in 17 Clinical Categories

\begin{tabular}{|c|c|c|c|c|c|}
\hline \multirow[b]{2}{*}{ (Group) } & \multirow[b]{2}{*}{ Number } & \multirow{2}{*}{$\begin{array}{l}\text { Male } \\
\text { female }\end{array}$} & \multicolumn{2}{|c|}{ Age } & \multirow{2}{*}{$\begin{array}{c}\text { Fasting serum } \\
\text { (arnitine }(\text { mean } \pm S E) \\
(\text { total } / \text { free })\end{array}$} \\
\hline & & & average & rangt & \\
\hline & & & \multicolumn{2}{|c|}{$y r$} & $\mu . M$ \\
\hline Normal & 16 & $8 / 8$ & 42 & $21-50$ & $79 \pm 3 / 49 \pm 3$ \\
\hline Back pain & 12 & $7 / 5$ & 46 & $30-55$ & $85 \pm 12 / 53 \pm 8$ \\
\hline Uterine myoma & 10 & $0 / 10$ & 53 & $32-50$ & $67 \pm 10 / 41 \pm 7$ \\
\hline Rheumatoid arthritis & 12 & $4 / 8$ & 40 & $25-54$ & $75 \pm 6 / 42 \pm 6$ \\
\hline Ischemic heart disease & 14 & $10 / 4$ & 63 & $41-63$ & $71 \pm 5 / 41 \pm 4$ \\
\hline Chronic obstructive lung disease & 16 & $12 / 4$ & 58 & $43-65$ & $84 \pm 7 / 51 \pm 7$ \\
\hline Carcinoma of the breast (stage I)* & 21 & $0 / 21$ & 54 & $34-63$ & $80 \pm 4 / 54 \pm 5$ \\
\hline Carcinoma of the breast (stage IV) $\neq$ & 14 & $0 / 21$ & 50 & $37-66$ & $63 \pm 15 / 39 \pm 10$ \\
\hline Carcinoma of the colon (stage I)* & 15 & $9 / 6$ & 53 & $47-64$ & $85 \pm 6 / 56 \pm \varepsilon$ \\
\hline Carcinoma of the colon (stage IV) + & 12 & $6 / 6$ & 56 & $42-62$ & $62 \pm 10 / 38 \pm 12$ \\
\hline Malignant melanoma (stage I)* & 9 & $4 / 5$ & 38 & $24-42$ & $65 \pm 9 / 49 \pm 8$ \\
\hline Malignant melanoma (stage IV) $\ddagger$ & 11 & $6 / 5$ & 40 & $33-56$ & $63 \pm 12 / 38 \pm ?$ \\
\hline Acute myelocytic leukemia & 14 & $10 / 4$ & 36 & $27-48$ & $78 \pm 9 / 40 \pm \delta$ \\
\hline Alcoholic cirrhosis & 36 & $24 / 12$ & 52 & $39-67$ & $51 \pm 9 \$ / 32 \pm 5 \S$ \\
\hline Regional ileitis & 9 & $6 / 3$ & 31 & $26-4$ & $67 \pm 11 / 40 \pm 6$ \\
\hline Cerebral vascular disease & 12 & $6 / 6$ & 67 & $48-71$ & $83 \pm 10 / 53 \pm 9$ \\
\hline Cholelithiasis & 14 & $6 / 8$ & 62 & $41-76$ & $80 \pm 11 / 52 \pm 6$ \\
\hline
\end{tabular}

Diet was uncontrolled.

* Localized lesion without detectable involvement of regional nodes or distant metastasis.

$\neq$ One or more metastatic lesions.

$\S P<0.05$ for comparison with normal group.

TABLE II

Phase B of the Study: Clinical and Nutritional Evaluation of Six Normal Subjects and Six Hypocarnitinemic Cirrhotic Patients

\begin{tabular}{|c|c|c|c|c|c|c|c|}
\hline & \multirow{2}{*}{$\begin{array}{c}\text { Normal } \\
\text { (average } \pm \mathrm{SE} \text { ) }\end{array}$} & \multicolumn{6}{|c|}{ Cirrhosis } \\
\hline & & 1 & 2 & 3 & 4 & 5 & 6 \\
\hline Age/sex & $31 \pm 3(4 \mathrm{M} / 2 \mathrm{~F})$ & $5 \mathrm{l} / \mathrm{F}$ & $63 / \mathrm{F}$ & $43 / \mathrm{F}$ & $52 / \mathrm{M}$ & $48 / F$ & $65 / \mathrm{M}$ \\
\hline Known duration of disease, $y r$ & - & 9 & 6 & 8 & 12 & 7 & 10 \\
\hline Hematocrit, \% & $38 \pm 2$ & 21 & 23 & 30 & 25 & 27 & 26 \\
\hline Albumin, $g / 100 \mathrm{ml}$ & $4.5 \pm 0.3$ & 1.6 & 2.4 & 2.5 & 1.3 & 2.0 & 2.2 \\
\hline Bilirubin, $m g / 100 \mathrm{ml}$ & $0.6 \pm 0.1$ & 3.5 & 5.3 & 7.7 & 4.9 & 5.0 & 8.2 \\
\hline Prothrombin time, $s$ & $12 \pm 0.05$ & 15 & 17 & 20 & 16 & 13 & 15 \\
\hline Creatinine clearance, $\mathrm{ml} / \mathrm{min}$ & $118 \pm 8$ & 52 & 74 & 48 & 71 & 83 & 44 \\
\hline Ascites* & 0 & +++ & ++ & +++ & +++ & +++ & ++ \\
\hline MAMC, \% of standard & $103 \pm 4$ & 70 & 65 & 67 & 70 & 64 & 64 \\
\hline TSF, \% of standard & $115 \pm 6$ & 15 & 2,2 & 11 & 30 & 15 & 20 \\
\hline Creatinine/ht index, \% of standard & $110 \pm 4$ & 43 & 52 & 56 & 41 & 53 & 62 \\
\hline \multicolumn{8}{|l|}{ Spontaneous daily intake: } \\
\hline Calories & $2,780 \pm 115$ & 920 & 1,120 & 830 & 610 & 1,160 & 850 \\
\hline Protein & $86 \pm 6$ & 20 & 31 & 21 & 18 & 20 & 16 \\
\hline Serum carnitine (total/free), $\mu \mathrm{M} \ddagger$ & $76 \pm 5 / 52 \pm 6$ & $20 / 6$ & $30 / 15$ & $26 / 11$ & $18 / 5$ & $33 / 17$ & $19 / 12$ \\
\hline
\end{tabular}

* Ascites was graded as follows:

+ , positive "puddle" sign;

++ , flank dullness up to anterior axillary line;

+++ , dullness extends medial to anterior axillary line; abdomen is distended but not tense; fluid wave; umbilicus flat;

++++ , abdomen tense with fluid wave and everted umbilicus; diaphragms elevated.

$\$$ During phase $A$ of the study. 
protein. lysine, and methionine was only $20-50 \%$ of RDA, and their intake of carnitine averaged only $29 \mu \mathrm{mol} /$ day (Table III). Meanwhile serum carnitine and 24-h urinary carnitine (total/free) averaged 36/15 $\mu \mathrm{M}$ and $38 / 12 \mu \mathrm{mol} / \mathrm{day}$, respectively (Fig. 2). In contrast, the six healthy controls ate 1.2-6 times the RDA of calories, carbohydrate, protein, lysine, and methionine, and 350-480 $\mu \mathrm{mol}$ of carnitine daily; their serum and urine levels (total/free) meanwhile averaged $80 / 40 \mu \mathrm{mol} /$ day (Table III, Fig. 2 ).

The six cirrhotic and six normal subjects now received, during days $6-12$, oral and parenteral nutrition furnishing each day $<10 \mu \mathrm{mol}$ carnitine and 80-86 g protein containing two to four times the RDA of lysine and methionine. In the control group, serumtotal and serum-free carnitine remained within the normal ranges; urinary excretion declined in 2 days to $100 / 55$ (total/free) $\mu \mathrm{mol} /$ day and remained at this level for the next 4 days. In the cirrhotics, serum concentration declined from the 6th-day value of $28 / 18$ (total/free) to $20 / 10 \mu \mathrm{M}$ on day 12 ; the reduction however was not significant $(P>0.05)$. Urine total carnitine remained in the range $15-30 \mu \mathrm{mol} /$ day during days 6-12. Administration of $500 \mu \mathrm{mol}$ D,L-carnitine/day during days 13-18 promptly increased serum level (of L-carnitine) to normal in the cirrhotics; their urinary total L-carnitine excretion rose progressively, reaching $150 \mu \mathrm{mol} / \mathrm{day}$ on day 18 . In the normals, serum level was not affected by the carnitine supplement; urinary total excretion increased to $260 \mu \mathrm{mol} / \mathrm{day}$.

Phase C. Seven of the cirrhotic patients identified in phase $\mathrm{A}$ as having hypocarnitinemia came to autopsy within the next 3 mo (Table IV). Their tissue levels were compared with those of eight nonhepatic patients with normal nutritional status (as evidenced by

TABLE III

Average Composition of Diets in Phase B for Six Normal (N) and Six Cirrhotic (C) Subjects

\begin{tabular}{|c|c|c|c|c|c|c|c|}
\hline \multirow[b]{2}{*}{ Nutrient/day } & \multirow[b]{2}{*}{ RDA* } & \multicolumn{2}{|c|}{ Days 1-6 } & \multicolumn{2}{|c|}{ Days $7-12$} & \multicolumn{2}{|c|}{ Days $13-18$} \\
\hline & & $x$ & $\mathrm{C}$ & $x$ & $\mathrm{C}$ & $N$ & $\mathrm{C}$ \\
\hline Calories & 2,400 & 2.790 & 1,068 & $2,4.30$ & 2,210 & 2,410 & 2.180 \\
\hline \multicolumn{8}{|l|}{ Carbohydrate, } \\
\hline g & - & 334 & 1.5 .5 & 289 & 325 & 284 & 338 \\
\hline Fat, $g$ & - & 110 & 40 & 105 & 63 & 105 & 57 \\
\hline \multicolumn{8}{|l|}{ Amino acids $\downarrow$} \\
\hline$g$ & 56 & 91 & 22 & 82 & 86 & 82 & 79 \\
\hline Lysine, $m g$ & 800 & 4,800 & 400 & 3,230 & 3,400 & 3,230 & 3,160 \\
\hline $\begin{array}{l}\text { Methionine, } \\
\text { mg }\end{array}$ & 1,100 & 2.400 & 20.5 & 2,050 & 2,170 & $2,0.50$ & 2.040 \\
\hline $\begin{array}{l}\text { L-Carnitine, } \\
\qquad \mu \mathrm{mol}\end{array}$ & 0 & 410 & 29 & $<10$ & $<10$ & $2.50 \$$ & $2.50 \$$ \\
\hline
\end{tabular}

For a $70-\mathrm{kg}$ adult male.

$\$$ Either as dietary protein, infused amino acids, or both.

$\$$ This value assumes zero carnitine in the "carnitine-free" diet.
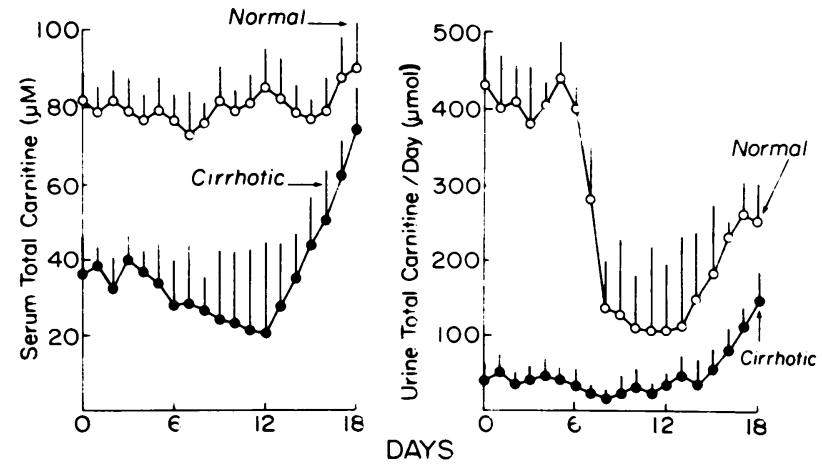

FIGURE 2 Fasting serum and urine total carnitine values (average $\pm \mathrm{SE}$ ) in six normal and six cirrhotic subjects during phase $B$ of the study. Nutritional intake during, days $1-6,7-12$, and $13-18$ is described in Table III.

body weight 105-140\% of ideal, and history negative for recent anorexia or weight loss) who died after an acute illness of a 1-3-day duration. In the cirrhotic patients' pectoral muscle, heart, liver, kidney, and brain, concentrations of both total and free carnitine were only $16-40 \%$ as great as in the nonhepatic, normally nourished cases $(P<0.05)$.

\section{DISCUSSION}

In seeking explanations for the subnormal serum, urine, and tissue levels of carnitine in the undernourished cirrhotics eating hospital diets ad lib, we must consider the dual source of carnitine in the body: (a) intake of preformed exogenous carnitine and (b) endogenous synthesis, from exogenous lysine and methionine contained in dietary protein. In the normal rat, body carnitine turns over approximately every 15 days (24) and over $90 \%$ is excreted unmetabolized in the urine (25). As a first approximation, we assume therefore that in normal man, urinary carnitine/day is equal to intake of dietary carnitine/day + carnitine synthesized endogenously/day.

The present study shows intake of exogenous carnitine by normal subjects eating a diet selected from 25 common foodstuffs (Table V) is $380-450 \mu \mathrm{mol}$, and a similar amount is excreted in the urine. Therefore, endogenous synthesis in normal individuals eating about $400 \mu \mathrm{mol}$ exogenous carnitine/day is probably close to zero. When exogenous intake is reduced below $10 \mu \mathrm{mol} / \mathrm{day}$, and the precursors continue to be supplied, urinary excretion by healthy subjects stabilizes at $100 \mu \mathrm{mol} /$ day, which probably approximates the rate of endogenous synthesis when the diet lacks carnitine. There is no nutritional requirement for exogenous carnitine in the rat or in man; thus, in normal subjects eating a carnitine-free diet, the rate of endogenous synthesis (about 100 
TABLE IV

Phase C of the Study: Postmortem Tissue Levels of Carnitine in Eight Normally Nourished Individuals Who Died from Acute Cause and in Seven Cirrhotic Patients Who Had Premortem Hypocarnitinemia

\begin{tabular}{|c|c|c|c|c|c|c|c|c|c|}
\hline \multirow[b]{2}{*}{$\begin{array}{l}\text { Age/ } \\
\text { sex }\end{array}$} & \multirow[b]{2}{*}{ Diagnosis } & \multirow[b]{2}{*}{$\begin{array}{l}\text { Duration } \\
\text { of illness }\end{array}$} & \multirow[b]{2}{*}{ Body wt } & \multirow{2}{*}{$\begin{array}{c}\text { Serum carnitine, } \\
\text { total/free } \\
\text { (time before death) }\end{array}$} & \multicolumn{5}{|c|}{ Tissue carnitine level (total) } \\
\hline & & & & & $\begin{array}{l}\text { Pectoral } \\
\text { muscle }\end{array}$ & Heart & Liver & Kidney & Brain \\
\hline & & & \% of ideal & $\mu M$ & \multicolumn{5}{|c|}{$\mu \mathrm{mol} / \mathrm{g}$ wet wt } \\
\hline $68 / F$ & $\begin{array}{r}\text { Pulmonary } \\
\text { embolus }\end{array}$ & 1 day & 130 & & 2.0 & 3.5 & 1.9 & 0.8 & 0.2 \\
\hline $76 / \mathrm{M}$ & $\begin{array}{l}\text { Acute chole- } \\
\text { cystitis; gram- } \\
\text { negative sepsis }\end{array}$ & 2 days & 105 & & 2.8 & 5.2 & 3.7 & 0.9 & 0.2 \\
\hline $44 / \mathrm{F}$ & $\begin{array}{l}\text { Cardiac } \\
\text { infarction }\end{array}$ & 2 days & 130 & & 3.1 & 3.5 & 3.5 & 1.1 & 0.3 \\
\hline $51 / \mathrm{F}$ & $\begin{array}{l}\text { Right cerebral } \\
\text { arterial } \\
\text { hemorrhage }\end{array}$ & 3 days & 120 & & 4.0 & 4.4 & 2.6 & 0.9 & 0.3 \\
\hline $34 / \mathrm{M}$ & $\begin{array}{l}\text { Dissecting aortic } \\
\text { aneurysm }\end{array}$ & 1 day & 105 & & 3.2 & 4.3 & 2.5 & 1.0 & 0.2 \\
\hline $60 / \mathrm{M}$ & $\begin{array}{l}\text { Myocardial } \\
\text { infarction }\end{array}$ & 2 days & 120 & & 2.1 & 5.7 & 2.3 & 1.4 & 0.3 \\
\hline $6 / \mathrm{M}$ & $\begin{array}{l}\text { Skull fractures; } \\
\text { cerebral } \\
\text { contusion }\end{array}$ & 1 day & 105 & & 3.5 & 5.7 & 3.8 & 0.9 & 0.5 \\
\hline $51 / \mathrm{M}$ & $\begin{array}{l}\text { Left cerebral } \\
\text { arterial } \\
\text { thrombosis }\end{array}$ & 2 days & 140 & & 4.6 & 6.0 & 2.9 & 1.4 & 0.4 \\
\hline $51 / \mathrm{F}$ & $\begin{array}{l}\text { Alcoholic } \\
\text { cirrhosis* } \ddagger\end{array}$ & $9 \mathrm{yr}$ & & $18 / 7 \quad(-23$ days $)$ & 0.2 & 1.3 & 1.1 & 0.4 & 0.04 \\
\hline $69 / \mathrm{F}$ & $\begin{array}{l}\text { Macronodular } \\
\text { cirrhosis; } \\
\text { hepatoma* }\end{array}$ & $9 \mathrm{yr}$ & & $31 / 12(-42$ days $)$ & 0.3 & 1.2 & 1.2 & 0.6 & 0.06 \\
\hline $53 / \mathrm{F}$ & $\begin{array}{l}\text { Alcoholic } \\
\text { cirrhosis* }\end{array}$ & $4 \mathrm{yr}$ & & 21/6 (-18 days) & 0.2 & 0.9 & 0.7 & 0.4 & 0.03 \\
\hline $65 / \mathrm{F}$ & $\begin{array}{l}\text { Alcoholic } \\
\text { cirrhosis* }\end{array}$ & $6 \mathrm{yr}$ & & $46 / 19$ (- 10 days $)$ & 0.8 & 1.4 & 0.5 & 0.1 & 0.09 \\
\hline $63 / \mathbf{M}$ & $\begin{array}{l}\text { Alcoholic } \\
\text { cirrhosis* }\end{array}$ & $5 \mathrm{yr}$ & & $42 / 15(-26$ days $)$ & 0.6 & 1.5 & 0.9 & 0.5 & 0.04 \\
\hline $54 / \mathrm{M}$ & $\begin{array}{l}\text { Alcoholic } \\
\text { cirrhosis } * \ddagger \S\end{array}$ & $11 \mathrm{yr}$ & & $20 / 7 \quad(-15$ days $)$ & 0.4 & 0.7 & 1.3 & 0.3 & 0.05 \\
\hline $63 / F$ & $\begin{array}{l}\text { Alcoholic } \\
\text { cirrhosis*\| }\end{array}$ & $6 \mathrm{yr}$ & & $24 / 14(-20$ days $)$ & 1.0 & 0.6 & 1.4 & 0.5 & 0.03 \\
\hline $\begin{array}{l}\text { Avera } \\
\text { Avera }\end{array}$ & $\begin{array}{l}e \pm S E \text {, eight norma } \\
e \pm S E \text {, seven cirrho }\end{array}$ & $\begin{array}{l}\text { y nourish } \\
\text { c patient }\end{array}$ & d patients & & $\begin{array}{l}3.2 \pm 0.3 \\
0.5 \pm 0.19\end{array}$ & $\begin{array}{l}4.8 \pm 0.4 \\
1.1 \pm 0.19\end{array}$ & $\begin{array}{l}2.9 \pm 0.2 \\
1.0 \pm 0.19\end{array}$ & $\begin{array}{l}1.0 \pm 0.1 \\
0.4 \pm 0.19\end{array}$ & $\begin{array}{c}0.3 \pm 0.0 \\
0.05 \pm 0.019\end{array}$ \\
\hline
\end{tabular}

* Last month of life characterized by jaundice, cachexia, anorexia, ascites, lethargy, and obtundation.

$\$$ Bleeding from esophageal varices during last month of life.

\$ Postportasystemic shunt.

" Postperitoneovenous (Leveen) shunt for intractable ascites.

I $P<0.05$ for difference between this value and corresponding value of normally nourished group. 
TABLE V

Carnitine Content of Foods Eaten by the Patients in Phase B

\begin{tabular}{llr}
\hline Food (wt of one serving in grams*) & $\mu \mathrm{mol} / \mathrm{g}^{*}$ & $\mu$ mol/serving \\
\hline Egg (50) & 0.05 & 2.50 \\
Chicken (50) & 0.60 & 30.00 \\
Steak (50) & 5.50 & 275.00 \\
Ground beef (50) & 3.00 & 150.00 \\
Carrots (50) & 0 & 0 \\
Green beans (50) & 0.05 & 2.50 \\
Peas (50) & 0.072 & 3.60 \\
Tomatoes (50) & 0.182 & 9.00 \\
Orange juice (50) & 0.110 & 5.50 \\
Apple juice (50) & 0.080 & 4.00 \\
Asparagus (50) & 0.080 & 4.00 \\
Applesauce (50) & 0.195 & 9.75 \\
Peaches (50) & 0.100 & 5.00 \\
Pears (50) & 0.170 & 8.50 \\
Pineapple (50) & 0.065 & 3.25 \\
Bread (23) & 0.05 & 2.50 \\
Potato (50) & 0 & 0 \\
Grits (10, dry) & 0.06 & 5.10 \\
Rice (10, dry) & 0.11 & 4.40 \\
Corn flakes (20, dry) & 0.59 & 11.80 \\
Graham crackers (16, dry) & 0.05 & 0.80 \\
Sustacal (50) & 0.076 & 3.80 \\
Margarine (20) & 0.065 & 1.30 \\
Milk (50) & 0.164 & 8.20 \\
Catsup (20) & 0.100 & 2.00 \\
. & &
\end{tabular}

*Wet weight except where "dry" is specified.

$\mu \mathrm{mol} / \mathrm{day})$ is adequate to maintain normal fatty acid metabolism within cells. This conclusion is supported by the fact that serum carnitine of normal subjects eating a carnitine-free, lysine- and methionine-rich diet remained normal while urinary excretion stabilized at $100 \mu \mathrm{mol} / \mathrm{day}$ (days 6-12, Fig. 2).

The subnormal serum, urine, and tissue carnitine levels in the cachectic cirrhotic subjects resulted from at least three factors. (a) Because of anorexia, their average spontaneous daily intake of exogenous carnitine was only $29 \mu \mathrm{mol}$ (days $1-6$ of phase B, Table III), (b) Anorexia also caused inadequate intake of dietary protein, including the carnitine precursors lysine and methionine (days 1-6, Table III). In the normal rat, these conditions, a carnitine-free diet deficient in either lysine or methionine, will rapidly cause depletion of carnitine in muscle, liver, kidney, and brain $(10-12)$. (c) But in cirrhotic man a third factor operates as well: endogenous biosynthesis of carnitine from lysine and methionine is defective. This abnormality is shown by the comparison of normal and cirrhotic subjects receiving the carnitine-free, lysineand methionine-rich nutritional regimen (days 6-12 of phase B, Fig. 2). While the normals synthesized and excreted about $100 \mu \mathrm{mol}$ total carnitine/day and maintained a normal serum level on this program, the cirrhotics' urinary excretion was only $15-30 \mu \mathrm{mol} /$ day and their serum total carnitine level was only $20 \mu \mathrm{M}$. If we assume that $>90 \%$ of body carnitine is excreted unmetabolized in the urine by both normal and cirrhotic humans, as by the normal rat (28), these data indicate that the capacity of the cirrhotic patients in phase B to synthesize carnitine was only $1 / 10$ th as great as in normals.

The assumption that carnitine is not further metabolized in cirrhotic patients may, however, not be correct. In the rat, inadequate intake of methionine causes deficiency of choline as well as of carnitine (26), Choline depletion causes accelerated turnover of body carnitine (25). This accelerated turnover results in large part from conversion of carnitine to $\beta$. methylcholine; in the methionine- and cholinedeficient rat, as much as $80 \%$ of a tracer dose of carnitine is excreted as $\beta$-methylcholine (25). Inasmuch as the spontaneous dietary intake of methionine of the cirrhotic patients in phase $B$ was only onefourth of the RDA (Table III), they may have had choline deficiency and accelerated conversion of carnitine to $\beta$-methylcholine. If so, a contributory mechanism for their carnitine depletion could have been accelerated conversion of carnitine to $\beta$-methylcholine, and their capacity for endogenous carnitine synthesis could be more than 1/10th of normal. Nevertheless, the fact that urinary excretion of carnitine virtually stopped while four times the RDA of methionine was being administered (days 6-12 of

TABLE VI

Comparison of Nutritional Indices, and Plasma Albumin, Bilirubin, and Prothrombin, in 16 Normals, 14 Hypocarnitinemic Cirrhotics, and 22 Normocarnitinemic Cirrhotics

\begin{tabular}{|c|c|c|c|c|c|c|c|}
\hline Group & $\begin{array}{l}\text { Serum carnitine, } \\
\text { (total/free) }\end{array}$ & $\begin{array}{l}\text { Creatinine/ } \\
\text { height ratio }\end{array}$ & MAMC & TSF & $\begin{array}{l}\text { Plasma } \\
\text { albumin }\end{array}$ & $\begin{array}{c}\text { Plasma } \\
\text { bilirubin }\end{array}$ & $\begin{array}{l}\text { Prothrombin } \\
\text { time }\end{array}$ \\
\hline & $\mu M$ & & " of standard & & $\mathrm{g} / \mathrm{l}(00 \mathrm{ml}$ & $m g / l(M) m l$ & $s$ \\
\hline Hypocarnitinemic cirrhotics & $36 \pm 4 / 17 \pm 3 *$ & $68 \pm 6^{*}$ & $71 \pm 5^{*}$ & $23 \pm 7^{*}$ & $1.4 \pm 0.3^{*}$ & $6.1 \pm 0.7^{*}$ & $19.3 \pm 1.1^{*}$ \\
\hline Normocarnitinemic cirrhotics & $66 \pm 9 / 34 \pm 6$ & $79 \pm 6^{*}$ & $84 \pm 5^{*}$ & $90 \pm 5$ & $2.9 \pm 0.6^{*}$ & $3.8 \pm 0.6^{*}$ & $13.3 \pm 0.6$ \\
\hline
\end{tabular}

* Differs from normal with $P<0.05$. 
phase B, Fig. 2) suggests that methionine and choline deficiencies were not the primary cause of the carnitine depletion, and that a substantial loss of endogenous synthetic capacity had indeed occurred.

The most likely reason for a loss of capacity to synthesize carnitine is inability to convert $\gamma$-butyrobetaine to carnitine (Fig. 1), a reaction which occurs only in the liver. However, impaired synthesis of trimethyllysine or butyrobetaine in extrahepatic tissues is also possible because of reduced muscle mass or diversion of lysine and methionine to other pathways in these patients with severe protein-calorie starvation. These alternative mechanisms can be tested in future studies by observing the effect of dietary supplements of trimethyllysine and of butyrobetaine on serum and urinary carnitine in hypocarnitinemic cirrhotic patients.

A contributory cause to the hypocarnitinuria in the hypocarnitinemic cirrhotics of phase B was their subnormal rate of glomerular filtration, as revealed by low creatinine clearance (Table II).

It is notable that in the normal subjects, when carnitine was removed from the diet (day $1-6$ of phase B, Fig. 2), carnitine excretion dropped $75 \%$ without any change in fasting serum levels. What was the signal to the kidney to retain carnitine on the low carnitine, lysine- and methionine-rich diet? One possibility is that postprandial hypercarnitinemia follows ingestion of carnitine-containing foods, and that the major excretion of carnitine occurs during the periods of elevated serum carnitine during the hours after such meals. Under these circumstances, removal of carnitine from the diet would reduce $24 \mathrm{~h}$ urinary carnitine without altering fasting serum carnitine. It is also possible that the renal tubular reabsorption of carnitine is influenced by the lysine and methionine intake.

Although nutrition was not evaluated in the nonhepatic patients in Table $I$, recent reports suggest the groups with metastatic cancer probably had a considerable prevalence of protein-calorie malnutrition $(12,13)$. Table I shows that stage 4 cancer patients had serum carnitine levels intermediate between normals and cirrhotics and not significantly different from either. Perhaps severe protein-calorie starvation without hepatic disease can cause a mild degree of carnitine deficiency in some individuals without hepatic disease. Nevertheless, the occurrence of a subnormal average total serum carnitine level $(<55 \mu \mathrm{M})$ only in the cirrhotic group among 17 clinical categories surveyed (Table I) indicates the importance of the hepatic biosynthetic capacity in preserving body carnitine stores during periods of protein deprivation.

Our conclusion that hypocarnitinemic cirrhotics have subnormal tissue contents of carnitine is derived from the postmortem comparison of their tissues with those of well-nourished individuals who died after an acute illness of $<$ a 3-day duration (Table IV). For several reasons, however, the data in Table IV provide only qualitative information on this question. (a) Even 1-3 days of acute illness might have altered the tissue levels in the previously wellnourished individuals who served as controls. (b) A contributory factor in the subnormal carnitine concentration of the cirrhotic livers could have been the increased content of collagen, inflammatory cells, and fat. (c) In the rat, fasting has been shown to increase liver carnitine $(27,28)$. Since both groups of Table IV were probably in a fasted state terminally, their postmortem liver carnitine values may have been correspondingly elevated.

Although the present study indicates that marked hypocarnitinemia ( $<33 \%$ of normal) is associated with depletion of tissue carnitine content (16-40\% of normal), previous studies $(19,29)$ have demonstrated that in normal subjects, serum carnitine did not correlate significantly with muscle carnitine content or with lean body mass. Thus, serum carnitine should not be regarded as a sensitive or precise indicator of the concentration of carnitine at its site of action in muscle cells.

What consequences could carnitine depletion have in cirrhotic patients? The hereditary type of deficiency causes myopathy, fatty liver, and cerebral disorders (6-9). Since all three of these abnormalities occur frequently in patients with advanced cirrhosis, it is possible that the presently demonstrated carnitine deficiency could play a role in the pathogenesis of these common manifestations of acquired liver disease. If so, correction of the carnitine deficiency by oral supplements of the compound may prove beneficial.

\section{REFERENCES}

1. Fritz, I. B. 1963. Carnitine and its role in fatty acid metabolism. Adv. Lipid Res. 1: 285-334.

2. Tanphaichitr, V., and H. P. Broquist. 1973. Role of lysine and $\epsilon-N$-trimethyllysine in carnitine biosynthesis. II. Studies in the rat. J. Biol. Chem. 248: 2176-2181.

3. Tanphaichitr, V., D. W. Horne, and H. P. Broquist. 1971. Lysine, a precursor of carnitine in the rat. $J$. Biol. Chem. 246: 6364-6366.

4. Strength, D. R., S. Y. Yu, and E. Y. Davis. 1965. Biosynthesis of carnitine: dietary factors that influence concentration of carnitine in tissue. In Recent Research on Carnitine, Its Relation to Lipid Metabolism. G. Wolf, editor, The M. I. T. Press, Cambridge, Mass. 45-46.

5. Wolf, G., and C. R. A. Berger. 1961. Studies on the biosynthesis and turnover of carnitine. Arch. Biochem. Biophys. 92: 360-365.

6. Vandyke, D. H., R. C. Griggs, W. Markesbery, and S. Di Mauro. 1975. Hereditary carnitine deficiency of muscle. Neurology. 25: 154-159.

7. Karpati, G., S. Carpenter, A. Engel, G. Watters, J. Allen, 
S. Rothman, G. Klassen, and O. Mainer. 1975. The syndrome of systemic carnitine deficiency. Clinical, morphologic, biochemical, and pathophysiologic features. Neurology. 25: 16-24.

8. Smyth, D. P. L., B. D. Lake, J. MacDermot, and J. Wilson. 1975. Letter: Inborn error of carnitine metabolism ("carnitine deficiency") in man. Lancet. I: 1198-1199.

9. Engel, A. G., and C. Angelini. 1973. Carnitine deficiency of human skeletal muscle with associated lipid storage myopathy: a new syndrome. Science (Wash. D. C.). 179: 899-901.

10. Tanphaichitr, V., and H. P. Broquist. 1973. Lysine deficiency in the rat: Concomitant impairment in carnitine biosynthesis. J. Nutr. 103: 80-87.

11. Tanphaichitr, V., M. S. Zaklama, and H. P. Broquist. 1973. Dietary lysine (LYS) and carnitine (CARN): Relation to growth and fatty liver in rat. Fed. Proc. Fed. Am. Soc. Exp. Biol. 32: 884. (Abstr.)

12. Bistrian, B. R., G. L. Blackburn, E. Hallowell, and R. Heddle. 1974. Protein status of general surgical patients. J.A.M.A. (J. Am. Med. Assoc.) 230: 858-860.

13. Bollet, A. J., and S. Owens. 1973. Evaluation of nutritional status of selected hospitalized patients. Am. J. Clin. Nutr. 26: 931-938.

14. Metropolitan Life Insurance Co. 1959. New weight standards for men and women. Statistical Bulletin 40: $1-4$.

15. Jelliffe, D. B. 1966. The assessment of the nutritional status of the community. WHO Monogr. Ser. 53: 1-35.

16. Gurney, J. M., and D. B. Jelliffe. 1973. Arm anthropometry in nutritional assessment-nomogram for rapid calculation of muscle circumference and cross-sectional muscle and fat areas. Am. J. Clin. Nutr. 26: 912915.

17. Miller, A. T., Jr., and C. J. Blyth. 1952. Estimation of lean body mass and body fat from basal oxygen consumption and creatinine excretion. J. Appl. Physiol. 5: 73-78.
18. Marquis, N. R., and I. B. Fritz. 1964. Enzymological determination of free carnitine concentrations in rat tissues. J. Lipid Res. 5: 184-187.

19. Cederblad, G., S. Lindstedt, and K. Lundholm. 1974. Concentration of carnitine in human muscle tissue. Clin. Chim. Acta. 53: 311-321.

20. Cederblad, G., and S. Lindstedt. 1971. Excretion of L-carnitine in man. Clin. Chim. Acta. 33: 117-123.

21. Pearson, D. J., J. F. A. Chase, and P. K. Tubbs. 1969. The assay of (-)-carnitine and its O-acyl derivatives. Methods Enzymol. 14: 612-622.

22. Food Policy and Food Science Service. 1970. Amino acid content of food, and biological data on proteins. Nutrition Division, Food and Agriculture Organization of the United Nations, Rome.

23. Campbell, D. P., D. E. Parker, and C. E. Anagnostopoulos. 1973. Survival prediction in portasystemic shunts: a computerized statistical analysis. Am. J. Surg. 126: 748751 .

24. Brooks, D. E., and J. E. McIntoch. 1975. Turnover of carnitine by rat tissues. Biochem. J. 148: 439-445.

25. Mehlman, M. A., D. G. Therriault, and R. B. Tobin. 1971. Carnitine-14C metabolism in choline-deficient, alloxan-diabetic choline-deficient and insulin-treated rats. Metab. Clin. Exp. 20: 100-107.

26. Tucker, H. F., and H. C. Eckstein. 1937. The effect of supplementary methionine and cystine on the production of fatty livers by diet. J. Biol. Chem. 121: 479-484.

27. Robles-Valdes, C., D. W. Foster, and J. D. McGarry. 1975. Role of carnitine in hepatic ketogenesis. Proc. Natl. Acad. Sci. U. S. A. 72: 4385-4388.

28. Robles-Valdes, C., J. D. McGarry, and D. W. Foster. 1976. Maternal-fetal carnitine relationships and neonatal ketosis in the rat. J. Biol. Chem. 251: 6007-6012.

29. Cederblad, G. 1976. Plasma carnitine and body composition. Clin. Chim. Acta. 67: 207-212. 